\title{
Front Matter: Volume 10315
}

, "Front Matter: Volume 10315," Proc. SPIE 10315, Optifab 2005: Technical Digest, 1031501 (2 May 2005); doi: 10.1117/12.2293191

SPIE. Event: Optifab 2005, 2005, Rochester, NY, United States 


\section{TECHNICAL DIGEST OF SPIE \\ SPIE-The International Society for Optical Engineering}

\section{Optifab 2005: Technical Digest}

2-5 May 2005

Rochester, New York, USA

Sponsored and Published by

SPIE-The International Society for Optical Engineering

Cosponsored by

APOMA-The American Precision Optics Manufacturers Association 
The summaries appearing in this book compose the digest of the technical conference cited on the cover and title page of this volume. Summaries were selected and subject to review by the editors and conference program committee. Some conference presentations may not be available for publication. The summaries published in this digest reflect the work and thoughts of the authors and are published herein as submitted. The publisher is not responsible for the validity of the information or for any outcomes resulting from reliance thereon.

Please use the following format to cite material from this book:

Author(s), "Title of Paper," in Optifab 2005: Technical Digest, SPIE Technical Digest TD03 (SPIE, Bellingham, WA, 2005) page numbers.

ISSN 0277-786X

ISBN 0-8194-5825-2

Published by

SPIE-The International Society for Optical Engineering

P.O. Box 10, Bellingham, Washington 98227-0010 USA

Telephone 1 360/676-3290 (Pacific Time). Fax 1 360/647-1445

http://www.spie.org

Copyright (C) 2005, The Society of Photo-Optical Instrumentation Engineers

Copying of material in this book for internal or personal use, or for the internal or personal use of specific clients, beyond the fair use provisions granted by the U.S. Copyright Law is authorized by SPIE subject to payment of copying fees. The Transactional Reporting Service base fee for this volume is $\$ 15.00$ per article (or portion thereof), which should be paid directly to the Copyright Clearance Center (CCC), 222 Rosewood Drive, Danvers, MA 01923. Payment may also be made electronically through CCC Online at http://www.copyright.com. Other copying for republication, resale, advertising or promotion, or any form of systematic or multiple reproduction of any material in this book is prohibited except with permission in writing from the publisher. The CCC fee code is 0277 $786 \times / 05 / \$ 15.00$.

Printed in the United States of America.

Proc. of SPIE Vol. $103151031501-2$ 


\section{Contents}

vii Conference Committee
ix Introduction

$1 \quad$ Precision finishing with magnetorheological (MR) jet technology [TD03-01]

W. Kordonski, A. Shorey, M. Tricard, QED Technologies (USA)

$4 \quad$ Free form surfaces: a challenge in optical manufacturing [TD03-02]

U. Birnbaum, O. Falkenstörfer, Th. Herrmann, J. Röder, R. Schreiner, T. Waak, JENOPTIK Laser, Optik, Systeme GmbH (Germany)

9 HyDra: A novel hydrodynamic polishing tool for high quality optical surfaces [TD03-03] E. Sohn, E. Ruiz, E. Luna, L. Salas, M. Núñez, J. Valdés, B. Martínez, I. Cruz-González, Univ. Nacional Autónoma de Mexico (Mexico)

12 Automatically high precision manufacturing technology for micro-optic subgroups [TD03-04]

T. Sure, Leica Microsystems GmbH (Germany); V. Guyenot, Fraunhofer-Institut für Angewandte Optik und Feinmechanik IOF (Germany); M. Gerhardt, OptoTech (Germany)

16 Precision cylinder optics for higher requirements [TD03-06]

D. Bergner, O. Falkenstörfer, D. Malina, J. Röder, R. Schreiner, JENOPTIK Laser, Optik, Systeme $\mathrm{GmbH}$ (Germany)

20 Research on fabrication of aspheres at the Center of Optics Technology (University of Applied Science in Aalen) [TD03-07]

R. Boerret, J. Burger, A. Bich, C. Gall, T. Hellmuth, Univ. of Applied Science Aalen (Germany)

24 Fabrication of blanks, figuring, polishing and testing of segmented astronomic mirrors for SALT and LAMOST projects [TD03-08]

A. P. Semenov, M. A. Abdulkadyrov, A. N. Ignatov, V. E. Patrikeev, V. V. Pridnya,

A. V. Polyanchikov, Y. A. Sharov, JSC Lytkarino Optical Glass Plant (Russia)

28 Optical manufacturing with magneto-rheological finishing (MRF) [TD03-09]

M. DeMarco, QED Technologies Inc. (USA)

$31 \quad$ Applying 5 S lean tools to optical fabrication [TD03-10]

G. J. Arserio, R. A. Nasca, Corning Tropel Corp. (USA)

35 UltraForm finishing [TD03-11]

E. Fess, J. Schoen, Univ. of Rochester (USA); M. Bechtold, D. Mohring, OptiPro Systems (USA)

38 Conditioning method development for $3 \mathrm{M}$ Trizact diamond tile fixed abrasives used in the finishing of brittle substrates [TD03-52]

T. Fletcher, F. T. Gobena, V. Romero, B. Sventek, 3M Co. (USA); W. Schoenhofen, 3M Co. (Germany) 
$41 \quad$ Glass molding technology [TD03-12]

H. Murakoshi, Toshiba Machine Co., Ltd. (Japan)

44 Grinding technoloy of aspheric molds for glass-molding [TD03-13]

Y. Kojima, Toshiba Machine Co., Ltd. (Japan)

47 A comparison of force and acoustic emission sensors in monitoring precision cylindrical grinding [TD03-14]

E. R. Marsh, J. A. Covey, The Pennsylvania State Univ. (USA); B. R. Knapp, Olympic Precision (USA); R. R. Vallance, George Washington Univ. (USA)

50 Development of a new process for manufacturing precision gobs out of new developed low Tg optical glasses for precise pressing of aspherical lenses [TD03-15]

R. Jaschek, C. Klein, C. Schenk, K. Schneider, J. Freund, S. Ritter, SCHOTT AG (Germany)

53 Optical materials micromechanical property database: fracture toughness and ductility [TD03-17]

S. Shafrir, J. J. Randi, J. C. Lambropoulos, Ctr. for Optics Manufacturing/Univ. of Rochester (USA)

61 Ultraprecision finishing of micro-aspherical surface by ultrasonic assisted polishing [TD03-53]

H. Suzuki, R. Kawamori, Y. Yamamoto, Kobe Univ. (Japan); M. Miyabara, Toyohashi Univ. of Technology (Japan); T. Okino, Y. Hijikata, T. Moriwaki, Kobe Univ. (Japan)

64 Where do optical tolerances come from? [TD03-18]

J. L. Bentley, Corning Tropel Corp. (USA) and The Institute of Optics/Univ. of Rochester (USA)

67 CAD integration: opening up new optical design possibilities [TD03-20]

J.-B. Haumonte, J.-C. Venturino, Optis (France)

70 Designing and specifying aspheres for manufacturability [TD03-21]

J. Kumler, Coastal Optical Systems Inc. (USA)

73 Measurement of mild aspheric surfaces with subaperture stitching interferometry [TD03-22]

P. E. Murphy, G. Forbes, J. Fleig, QED Technologies (USA)

76 Correcting transmitted wavefronts using magnetorheological finishing (MRF) [TD03-23]

C. Hall, S. O'Donohue, P. Dumas, QED Technologies (USA)

79 MTF testing of imaging systems: A practical solution for production environments [TD03-24]

S. P. Sadoulet, Edmund Optics, Inc. (USA) 
82 The ultrahigh precision form measurement of small, steep-sided aspheric moulds, incorporating novel hardware and software developments [TD03-25]

M. W. Mills, M. J. Hutchinson, Taylor Hobson Ltd. (United Kingdom)

86 Tactile sensor for aspheric measurements [TD03-26]

R. Schoene, Univ. of Passau (Germany); J. Zaenkert, LINOS Photonics GmbH \& Co. KG

(Germany); T. Hanning, Univ. of Passau (Germany)

\section{POSTER SESSION: OPTICAL MANUFACTURING}

90 A novel polishing head with a gimbals-like structure for the high-speed polishing process [TD03-27]

H. Lee, N. Lee, Hanbat National Univ. (South Korea); C. Song, H. Lee, Y. Shin, C. Park, Korea Institute of Machinery and Materials (South Korea)

93 Design and fabrication of microlens array for VCSEL to fiber coupling [TD03-30]

S. Kim, H. Kim, J. Lim, J. Han, S. Kang, Yonsei Univ. (South Korea)

97 Several technical problems of high power He-Ne laser with flat discharge tube [TD03-31] Y. Ling, Southeast Univ. (China)

100 Prediction of the removal profile for tools having a finite contact patch [TD03-34] C. Bouvier, S. M. Gracewski, Univ. of Rochester (USA) and Ctr. for Optics Manufacturing (USA); E. Fess, Univ. of Rochester (USA); S. J. Burns, Univ. of Rochester (USA) and Ctr. for Optics Manufacturing (USA)

104 Fabrication of affordable aspheric mirrors by electroforming [TD03-35]

B. Stein, NiCoForm, Inc. (USA); A. Caneer, Advanced Optical Systems, Inc. (USA)

106 GRANTECAN telescope M3 mirror manufacturing [TD03-36]

M. A. Abdulkadyrov, A. N. Ignatov, V. E. Patrikeev, V. V. Pridnya, A. V. Polyanchikov, A. P. Semenov, Y. A. Sharov, JSC Lytkarino Optical Glass Plant (Russia)

$110 \quad M 1$ and $M 2$ mirrors manufacturing for VISTA telescope [TD03-37]

M. A. Abdulkadyrov, A. N. Ignatov, V. E. Patrikeev, V. V. Pridnya, A. V. Polyanchikov, A. P. Semenov, Y. A. Sharov, JSC Lytkarino Optical Glass Plant (Russia); E. Atad-Ettedgui, I. Egan, R. J. Bennet, S. Craig, UK Astronomy Technology Ctr. (United Kingdom)

114 Development of compliant tools and processes to polish axisymmetric surfaces [TD03-39] C. Bouvier, S. M. Gracewski, Univ. of Rochester (USA) and Ctr. for Optics Manufacturing (USA); E. Fess, Univ. of Rochester (USA); S. J. Burns, Univ. of Rochester (USA) and Ctr. for Optics Manufacturing (USA)

118 Double-sided lapping and polishing of optical materials [TD03-40]

M. Naselaris, Sydor Optics, Inc. (USA) 
POSTER SESSION: SURFACE CHARACTERIZATION, CHEMISTRY, AND MATERIAL SCIENCE

121 Comparative micro-indentation and dislocation activity in silicon and CaF2: a model [TD03-41]

Q. Zhang, J. C. Lambropoulos, Ctr. for Optics Manufacturing/Univ. of Rochester (USA)

125 Use of nanocrystalline ceria in EUV lithography optics polishing [TD03-42]

P. G. Murray, Nanophase Technologies Corp. (USA); T. Böhm, H. Maltor, Carl Zeiss SMT AG (Germany)

129 Effects of glass mechanical properties on polishing [TD03-43]

S. N. Shafrir, J. C. Lambropoulos, Ctr. for Optics Manufacturing/Univ. of Rochester (USA)

POSTER SESSION: OPTICAL METROLOGY AND TESTING

134 Power spectral density plots inside MRF spots made with a polishing abrasive-free MR fluid [TD03-45]

J. E. DeGroote, The Institute of Optics/Univ. of Rochester (USA) and Univ. of Rochester (USA); A. E. Marino, Univ. of Rochester (USA); K. E. Spencer, S. D. Jacobs, The Institute of Optics/Univ. of Rochester (USA) and Univ. of Rochester (USA)

139 Phase retrieval as an optical metrology tool [TD03-46]

G. R. Brady, J. R. Fienup, The Institute of Optics/Univ. of Rochester (USA)

142 Imaging of biological tissues with optical coherence tomography system using JonesMueller calculus [TD03-47]

S. Firdous, M. Ikram, Pakistan Institute of Engineering and Applied Sciences (Pakistan)

149 Mechanical errors related to interferometric radius of curvature measurements [TD03-48] P. J. McGhee, Univ. of Rochester (USA) and Fisba Optik LLC (USA); J. Nemechek, Fisba Optik LLC (USA)

153 The sum of all errors [TD03-50]

B. Light, Optimax Systems (USA)

156 Calibrating interferometric imaging distortion using subaperture stitching interferometry [TD03-51]

S. O'Donohue, P. Murphy, G. Forbes, J. Fleig, P. Dumas, QED Technologies (USA) 


\title{
Conference Committee
}

\author{
Conference Chairs \\ Robert E. Fischer, OPTICS 1 Inc. (USA) \\ Masahide Katsuki, Toshiba Machine Company (Japan) \\ Matthias Pfaff, OptoTech Optikmaschinen GmbH (Germany) \\ Kathleen A. Richardson, School of Optics/University of Central Florida \\ (USA)
}

Program Committee

Michael J. Bechtold, OptiPro Systems (USA)

Christopher T. Cotton, ASE Optics, Inc. (USA)

Walter C. Czajkowski, Edmund Industrial Optics (USA)

Michael A. DeMarco, QED Technologies (USA)

Edward M. Fess, University of Rochester (USA)

John T. Fried, LOH Optical Machinery (USA)

Donald Golini, QED Technologies (USA)

Heidi Hofke, OptoTech Optical Machinery Inc. (USA)

Arne Lindquist, Schneider Optical Machines, LLC (USA)

Michael P. Mandina, Optimax Systems, Inc. (USA)

Paul Meier-Wang, AccuCoat Inc. (USA)

Richard A. Nasca, Corning Tropel Corporation (USA)

Michael N. Naselaris, Sydor Optics, Inc. (USA)

John J. Nemechek, Fisba Optik LLC (USA)

Robert F. Novak, Monroe Community College (USA)

Carolyn Russell, QED Technologies (USA)

Annette Sansone, University of Rochester (USA)

Jim M. Sydor, Sydor Optics, Inc. (USA)

David Young, Corning Tropel Corporation (USA) 
Proc. of SPIE Vol. 10315 1031501-8

Downloaded From: https://www.spiedigitallibrary.org/conference-proceedings-of-spie on 26 Apr 2023 Terms of Use: https://www.spiedigitallibrary.org/terms-of-use 


\section{Introduction}

This conference is the joint effort of SPIE-The International Society for Optical Engineering and APOMA-The American Precision Optics Manufacturers Association to host a forum and venue for worldwide experts and practitioners to gather, share knowledge, and discuss the future of optical fabrication.

The first Optifab conference was successfully held in May 2003 in Rochester, NY, where exhibitors from Europe, the United States, and Japan showcased machinery and equipment for the optical fabrication community and provided the unique opportunity to observe "on-the-shop-floor" demonstrations. Optifab was purposely chosen to alternate with the semi-annual Optatec exhibition in Frankfurt, Germany to provide an optical manufacturing fabrication experience in North America. Responses from our industry colleagues, as well as those from universities who carry out research in optics manufacturing science, have been overwhelmingly positive.

The technical venue of Optifab 2005 continues to leverage the international participation and expertise in the fabrication, processes, materials and metrology areas. The topics for the digest include a diverse range of new and emerging fabrication related technologies across the globe. Authors were asked to concentrate on novel and revolutionary processes, applications, and commercialization of technology rather than research fundamentals. Overall, we believe you will find the technical digest to be a great value and allow you to see first-hand the efforts of the leading international scientists, engineers, and manufacturers in manufacturing methods.

You will find topics to include MRF, glass molding, electroforming, microlenses, and many more advanced technologies. Technologies including telescope optics, free form surfaces, aspheric manufacturing, and other emerging technologies will be presented. Material and surface characterization and chemistry are well covered, as are metrology and testing. Optifab clearly represents a comprehensive state-of-the-art conference where the very latest in a wide variety of methods in optical manufacturing will be presented and discussed.

We express our sincere thanks to all those who worked directly or indirectly to create the program and attract the attendees for a successful conference.

Robert E. Fischer Masahide Katsuki Matthias Pfaff Kathleen A. Richardson 
Proc. of SPIE Vol. 10315 1031501-10 Downloaded From: https://www.spiedigitallibrary.org/conference-proceedings-of-spie on 26 Apr 2023
Terms of Use: https://www.spiedigitallibrary.org/terms-of-use 